\title{
Chemo-Divergence in Essential Oil Composition among Thirty One Core Collections of Ocimum sanctum L. Grown under Sub-Tropical Region of Jammu, India
}

\author{
S. Kitchlu' ${ }^{1}$, Rekha Bhadauria ${ }^{2}$, Gandhi Ram ${ }^{1 *}$, Kushal Bindu ${ }^{3}$, Ravi K. Khajuria ${ }^{3}$, Ashok Ahuja ${ }^{1}$ \\ Biodiversity \& Applied Botany Division, CSIR-Indian Institute of Integrative Medicine, Jammu, India; ${ }^{2}$ School of Studies in Botany, \\ Jiwaji University, Gwalior, India; ${ }^{3}$ Instrumentation Division, CSIR-Indian Institute of Integrative Medicine, Jammu, India. \\ Email: gram@iiim.ac.in
}

Received October $26^{\text {th }}, 2012$; revised November $28^{\text {th }}, 2012$; accepted December $5^{\text {th }}, 2012$

\begin{abstract}
Evaluation of thirty one core collections of Ocimum sanctum L. synonyms $O$. tenuiflorum L. collected from different ecological regions representing contrasting environment of India was carried out. All the collections were grown under sub-tropical region of Jammu, India. Study revealed wide range of variability in quantitive and qualitative attributes of oil. Essential oil content ranged between $0.16 \% \pm 0.01 \%-0.55 \% \pm 0.08 \%$ showing the presence of fifteen constituents. Methyl eugenol $(1.54 \%-93.16 \%)$ and Eugenol $(0.06 \%-70.41 \%)$, were the major constituent. The other major constituent of the oil was $\beta$-Caryophyllene $(4.60 \%-33.77 \%)$ which was detected in almost all the collections. Borneol, Copane, $\alpha$ Caryophyllene were other constituents detected in almost all the accessions. $\alpha$ selinene was detected in traces in only three accessions (OS-01, OS-03, OS-50) and $\beta$-selinene was detected in four accessions (OS-01, OS-03, OS-50, OS-72. Accession OS-70 collected from Patna, showed distinct chemical profile having $\beta$-Elemene (32.81\%), $\beta$-Caryophyllene (16.37\%), Germacrene-D (18.05\%), $\beta$-Ocimene (17.69\%) and Copane (5.738\%). Being distinct in oil profiling, Patna collection was designated as distinct chemotype. Collections OS-50 from Gwalior from Central India and OS-59 from Rajkot Western India have been identified as methyl eugenol (93.16\%) and eugenol (70.41\%) rich genotypes. The data collected provided useful information with respect to composition of essential oil among core collection evaluated representing various agro-climatic zones.
\end{abstract}

Keywords: $\beta$-Caryophyllene; Chemotype; Eugenol; Germacrene-D; Methyl Eugenol; $\beta$-Ocimene; Variability

\section{Introduction}

Genus Ocimum belonging to family Lamiaceae, consists of about 160 species [1] represents versatile group of aromatics. It is well discussed in Ayurveda as healing system. Ocimum sanctum (Tulsi) leaves have potent medicinal properties, acting as an expectorant and antiseptic, in addition to having use as insect-repellent [2]. Leaves are diaphoretic, anti-periodic; they are also used in bronchitis, gastric and hepatic disorders. Decoction of leaves is recommended for cough, malaise and in colds. It is a good mosquito repellant as well. Oil extracted from flowers is used in skin diseases and ring worm infection. Various studies have been performed with Ocimum sanctum for its antibacterial, antioxidant, antiulceric, antimalarial, antidiabetic, anti-inflammatory, antilipidemic, anticancer and immunomodulatory properties [3]. The oils from the leaves of $O$. basilicum and $O$. sanctum contain phenols as aldehydes [4].

${ }^{*}$ Corresponding author.
The therapeutic value of this is ascribed to its essential oils contents $[5,6]$. The perfume, pharmacy and food industries use aromatic essential oil extracted from the leaves and flowers of basil in variety of products [6]. The European genotype or a sweet basil is considered to have the highest quality aroma, containing linalool and methyl chavicol as major constituents [7]. Seasonal variation in the content of essential oil and its major constituents eugenol, methyl eugenol, and caryophyllene, in leaves of $O$. sanctum has been reported [8]. Eugenol-rich (54\% of essential oil) genotype of sacred basil $O$. sanctum has been identified [9]. Use of sensitive analytical tools, GCMS of the essential oil of $O$. sanctum leaves allowed the separation of 46 compounds of which 31 were completely or partially identified [10].

The therapeutic potential is distributed variably in offtypes of Ocimum sanctum L. of different geographical and agro-climatic zones which implies that there is morpho-chemical and molecular diversity in it $[11,12]$. The natural variability needs to be studied and tapped for 
characterization of elite genotypes having desired combination of characters. This is important from commercial and pharmaceutical point of view to identify distinct biomolecule rich cultivar for bioprospection. The present proposed study is aimed to evaluate chemo-variation among thirty one core collections representing diverse agroclimatic regions of India. This will provide breeders an ample scope to undertake screening and selection of chemotypes and identify newer chemotypes. Based on the recorded distinct chemo profiling "elite" strains could be characterized for exploitation commercially for bioprospection of their value added products.

\section{Material and Methods}

\subsection{Plant Material}

Thirty one collections of Ocimum sanctum L. were subjected to evaluate oil profiling. Among these two accessions OS-06 and OS-07, GAU-2 (Shyam Tulsi) and IC 75730 (Puja Tulsi) were procured from NBPGR Delhi and remaining twenty nine core collections accessions were collected from different ecological regions of India ranging from sea level to 1220 masl. The details of various eco-regions where from these core collections were resourced are given in Table 1.

Table 1. Resource Locations of various core collections of Ocimum sanctum grown under Jammu conditions.

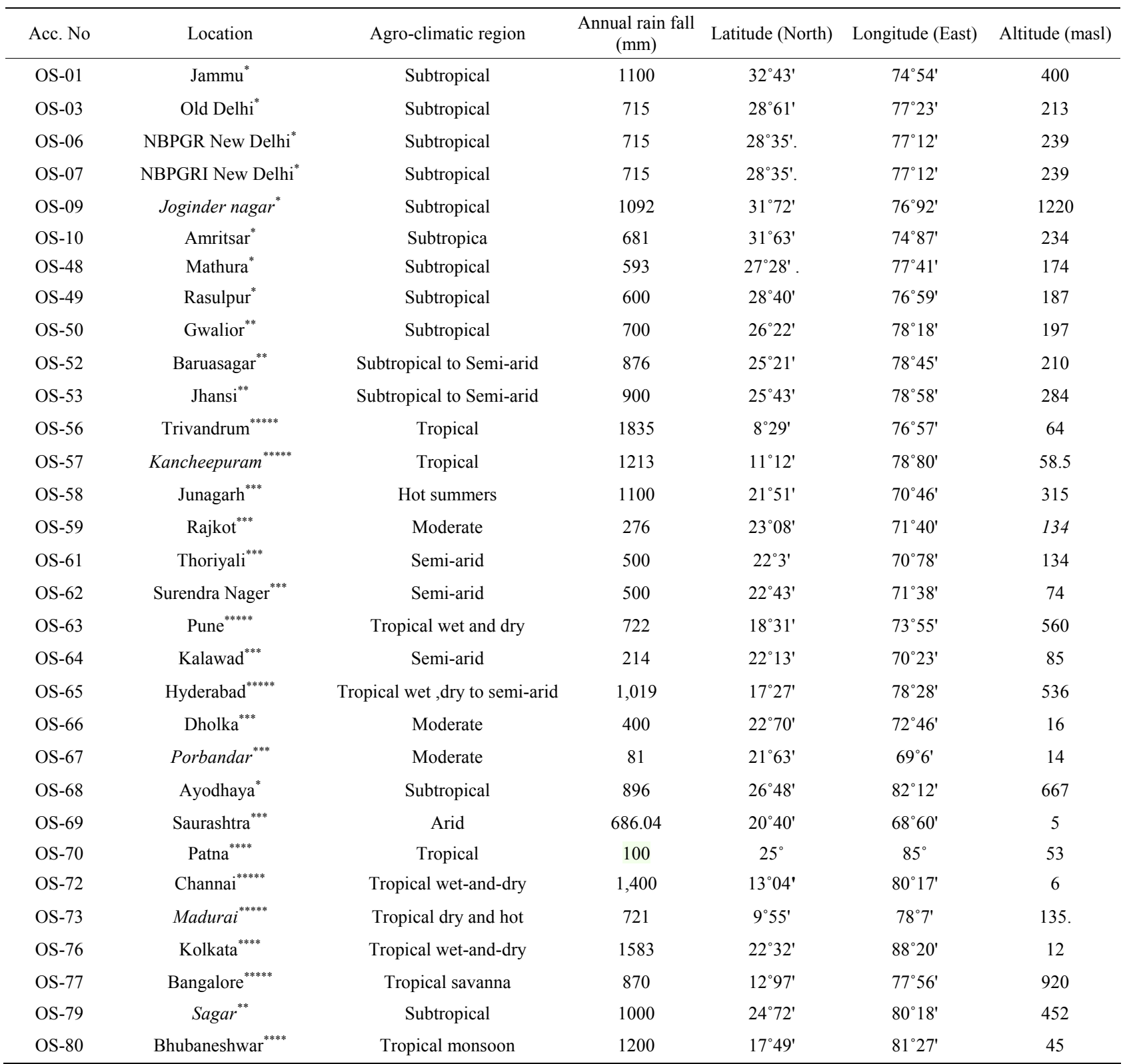

Northern India $^{*}$, Central India ${ }^{* *}$, Western India ${ }^{* * *}$, Eastern India $^{* * * *}$, Southern India ${ }^{* * * *}$. 
Seeds of all the core collections were subjected to seed viability test by triphenyl tetrazolium chloride (TTC) solution before sowing for raising nursery in well prepared pots in the second week of April. Six week old seedlings of all the accessions were planted in Farm Yard Manure (FYM) treated experimental plots during 2009 and 2011 at Experimental Farm of the Institute $\left(32^{\circ} 44^{\prime} \mathrm{N}\right.$ Latitude and $74^{\circ} 55^{\prime} \mathrm{E}$ Longitude and 400 masl) with a temperature ranging from $5^{\circ} \mathrm{C}-45^{\circ} \mathrm{C}$ and total rain fall $500 \mathrm{~mm}$ with plant distance of $50 \mathrm{cms}$. The soil of experimental plots was sandy loam with $\mathrm{pH} 6.8$, organic carbon $0.27 \%$, available nitrogen, phosphorous and potash (200 kg/ha, $14 \mathrm{~kg} / \mathrm{ha}$ and $136 \mathrm{~kg} / \mathrm{ha})$ respectively.

\subsection{Essential Oil Extraction}

Freshly harvested foliage $(100 \mathrm{gm})$ was used for extraction of essential oil by hydro-distillation method using Clevenger-type apparatus at $60^{\circ} \mathrm{C}$ for $3 \mathrm{~h}$. The oil was further analysed by the combination of GC and GC-MS. Essential oil content (percentage) was determined on air dried weight basis as an average of three samples. Mean $(\mathrm{X})$ : The mean value of the character was worked out by dividing the totals by corresponding number of observations.

Mean: Sum of X values/N (Number of values). Range: Lowest and highest values of each of character were recorded. Standard error: Standard error of difference of two means was calculated with the help of error mean square from the analysis of variance.

GC was performed on Perkin Elmer (USA) make gas chromatograph model auto system XL, equipped with FID and fused silica capillary column $(30 \mathrm{~m} \times 0.32 \mathrm{~mm}$ ID, $0.25 \mu \mathrm{m}$ film thickness) coated with dimethyl polysiloxane (RTX-1). Restek (Bellefonte, PA, USA).

GC analysis: Column oven temperature was programmed from $50^{\circ} \mathrm{C}-240^{\circ} \mathrm{C}$ at $5^{\circ} \mathrm{C}$ per min. Injector and detector temperatures were optimized at $250^{\circ}$ and $270^{\circ} \mathrm{C}$ respectively. Nitrogen gas at a flow rate of $1 \mathrm{~mL} / \mathrm{min}$ was used as the mobile phase. Injector split ratio was 1:80.

Gas chromatograph-mass spectrometer: GC-MS analysis was carried out on a Varian GC-MS 4000 fitted with a Varian Factor Four VF-5 ms fused silica capillary column $(30 \mathrm{~m} \times 0.25 \mathrm{~mm}$ id, film thickness $0.25 \mathrm{um})$. Temperature programming of oven was from $50^{\circ} \mathrm{C}$ to $240^{\circ} \mathrm{C}$ at $5^{\circ} \mathrm{C} / \mathrm{min}$ rising rate. Helium was used as carrier gas at flow rate of $1 \mathrm{ml} / \mathrm{min}$. Mass spectra were recorded over 50 - 300 amu range at 1 scan per sec with E.I. at 70 $\mathrm{eV}$.

Identification of peaks was carried out by comparing their retention times with authentic samples injected under similar chromatographic conditions. Comparison of Kovat indices with literature values was carried out. The mass spectra were compared with those reported in the
NIST and WILEY computer libraries and those published in literature [13] The relative amount (\%) of individual components of the oil is expressed as percent peak area relative to total peak area from the GC/FID analyses of the whole extracts.

\section{Results and Discussion}

The chemical constituents of oil obtained from various samples were examined by the combination of GC, $\mathrm{GC}-\mathrm{MS}$ and Kovat indices and data recorded is presented in Table 2.

The essential oil percentage of various accessions analyzed ranged between $0.16 \% \pm 0.01 \%-0.55 \% \pm$ $0.08 \%$ with a mean value of $0.35 \%$, which is comparable to earlier published reports [14-20]. The analysis of the oil showed the presence of fifteen constituents in $99.36 \%$ of the total volatile oil. Content of each constituent was compared among various collections. Analysis revealed methyl eugenol content between $1.54 \%$ - 93.16\%, with a mean value of $73.89 \%$. Among the various collections methyl eugenol content ranged between $90.50 \%-93.16 \%$ in OS-59, OS-61, OS-62 and OS-65. These collections were designated as methyl eugenol rich clones. In accession OS-48, OS-49, OS-52, OS-53, OS-64, OS-67, OS73 , OS-76 and OS-79, methyl eugenol content re- corded as $80.15 \%-88.19 \%$. The oil profiling of OS-01, OS-03, OS-09, OS-10, OS-50, OS-68 and OS-69 show that these collections are rich in eugenol constituent and eugonal content ranged between $0.06 \%$ - $70.41 \%$ with a mean value of $30.37 \%$. Identification of methyl eugenol rich collection which showed traces of eugenol content or absence possibly might be due to methylation of eugenol [21]. The occurrence eugenol is considered as of great ecological significance, it is documented to be an inhibitor of herbivory [22-24] as well as a good nematocide $[25,26]$ fungicide $[27,28]$ and bacteriocide [29]. Contrary to this, methyleugenol is an important insect pollinator attractant in many flowers, for pollinating moths and beetles in particular, and is a female phero- mone mimic for several fruit flies [30].

$\beta$-Caryophyllene was identified as major constituent which was detected in almost all the analysed collections. Its content ranged between $4.60 \%-33.77 \%$, with highest value $(33.77 \%)$ recorded in accession OS-01 collected from Jammu. The presence of $\alpha$-Caryophyllene in high proportion (19.42\%) was only detected in (OS-01) whereas $\alpha$-Caryophyllene Borneol, Copane were detected in almost all the accessions. $\boldsymbol{\alpha}$-selinene was present in OS-01, OS-03 and OS-50 in traces and $\beta$-selinene was detected in four accessions (viz. OS-01, OS-03, OS-50 and OS-72). $\triangle$ Cadinene, Elemol, Linalool and Caryophyllen oxide were present in traces in some accessions. The collection OS-70 from Patna, Bihar showed $\beta$-Ele- 
Ocimum sanctum L. Grown under Sub-Tropical Region of Jammu, India

Table 2. Essential oil array of various core collections of Ocimum sanctum L: Relative percentage of various components.

\begin{tabular}{|c|c|c|c|c|c|c|c|c|c|c|c|c|c|c|c|}
\hline $\begin{array}{l}\text { Acc } \\
\text { No }\end{array}$ & $\begin{array}{c}\beta- \\
\text { Ocimene }\end{array}$ & Linalool & Borneol & Euqenol & Copane & $\begin{array}{c}\beta- \\
\text { Elemene }\end{array}$ & $\begin{array}{c}\text { Methyl } \\
\text { Eugenol }\end{array}$ & $\begin{array}{l}\beta \text {-Caryo- } \\
\text { phyllene }\end{array}$ & $\begin{array}{l}\alpha \text {-Caryo } \\
\text { phyllene }\end{array}$ & $\begin{array}{l}\text { Germa } \\
\text { crene-D }\end{array}$ & $\begin{array}{c}\beta \\
\text { selinene }\end{array}$ & $\begin{array}{c}\alpha \\
\text { Selinene }\end{array}$ & $\begin{array}{c}\text { Delta } \\
\text { Cadinene }\end{array}$ & Elemol & $\begin{array}{l}\text { Caryo- } \\
\text { phyllene } \\
\text { oxide }\end{array}$ \\
\hline OS-01 & 3.91 & & 0.63 & 26.77 & 1.83 & 2.01 & & 33.77 & 19.42 & 6.52 & 0.57 & 0.52 & & & 0.39 \\
\hline OS-03 & & & 0.50 & 64.22 & & 10.20 & & 21.00 & 2.05 & & 0.15 & 0.28 & 0.10 & 0.1 & 0.15 \\
\hline OS-06 & & 0.097 & 1.75 & 0.84 & 1.16 & 0.52 & 79.55 & 10.62 & 1.05 & 3.25 & & & 0.27 & 0.01 & 0.05 \\
\hline OS-07 & & 0.063 & 1.25 & & 1.2 & 0.39 & 78.74 & 12.19 & 1.22 & 3.83 & & & 0.30 & & \\
\hline OS-09 & 0.73 & 0.867 & 3.43 & 44.95 & 3.85 & 1.31 & & 30.03 & 3.15 & 7.34 & & & 1.06 & 0.25 & 1.27 \\
\hline OS-10 & 0.70 & 0.911 & 3.49 & 45.48 & 3.82 & 1.30 & & 29.56 & 3.17 & 7.28 & & & 1.05 & 0.22 & 1.3 \\
\hline OS-48 & & & 0.14 & 0.60 & & & 87.65 & 9.47 & 0.89 & 0.19 & & & 0.03 & & 0.06 \\
\hline OS-49 & & & 0.34 & & & 0.59 & 88.19 & 8.66 & 0.83 & 0.37 & & & 0.03 & 0.02 & 0.05 \\
\hline OS-50 & & & & 70.41 & & 12.92 & & 12.34 & 1.34 & & 0.17 & 0.22 & & 0.18 & 0.31 \\
\hline OS-52 & 2.07 & & 0.19 & 0.14 & 0.89 & 3.24 & 82.80 & 7.05 & 0.66 & 1.76 & & & 0.21 & 0.08 & 0.09 \\
\hline OS-53 & & & 1.01 & & 0.45 & 2.43 & 85.80 & 6.46 & 0.64 & 1.19 & & & 0.11 & & \\
\hline OS-56 & & & & 20.97 & & & 25.16 & 11.8 & & 15.45 & & & & & \\
\hline OS-57 & & 0.178 & 1.64 & & 2.82 & 0.77 & 78.49 & 8.09 & 0.81 & 5.36 & & & 0.72 & & 0.18 \\
\hline OS-58 & 0.33 & 0.078 & 2.14 & 0.06 & 1.02 & 2.57 & 79.94 & 8.87 & 0.86 & 2.91 & & & 0.24 & 0.08 & 0.02 \\
\hline OS-59 & & & 0.15 & & & 0.62 & 93.16 & 4.60 & 0.44 & 0.25 & & & & & 0.05 \\
\hline OS-61 & & & & & & 0.77 & 90.66 & 7.04 & 0.66 & & & & & & \\
\hline OS-62 & & & 0.29 & & 0.11 & 2.04 & 90.50 & 5.48 & 0.51 & 0.36 & & & & & \\
\hline OS-63 & & & & 66.98 & & & 1.54 & 24.18 & 2.56 & 2.52 & & & 0.3 & & 0.22 \\
\hline OS-64 & 0.40 & & 0.35 & 0.22 & 0.35 & 3.78 & 82.49 & 9.69 & 0.88 & 0.70 & & & 0.12 & 0.03 & 0.11 \\
\hline OS-65 & & & & 0.15 & & 1.17 & 90.92 & 5.58 & 0.88 & & & & & & 0.44 \\
\hline OS-66 & & & 0.75 & & 1.35 & & 77.15 & 14.39 & 1.32 & 3.31 & & & 0.30 & & \\
\hline OS-67 & & & & & 0.20 & & 86.12 & 10.83 & 1.00 & 0.51 & & & 0.07 & & \\
\hline OS-68 & 6.58 & & & 22.58 & 3.44 & 19.75 & & 27.20 & & & & & & & \\
\hline OS-69 & & & & 54.38 & & & & 30.35 & 1.60 & 2.79 & & & 0.46 & & \\
\hline OS-70 & 17.67 & & & & 5.73 & 32.81 & & 16.37 & 0.84 & 18.05 & & & 1.92 & & \\
\hline OS-72 & & & 1.06 & & 4.50 & 0.45 & 74.55 & 9.10 & 0.93 & & 6.68 & & 0.76 & & 0.25 \\
\hline OS-73 & & & 1.18 & & 0.56 & 0.76 & 87.39 & 6.63 & 0.66 & 1.31 & & & & & \\
\hline OS-76 & & & & 3.55 & & & 80.15 & & & & & & & & \\
\hline OS-77 & & & & 59.64 & & & 6.38 & 28.24 & & & & & & & 2.89 \\
\hline OS-79 & & & & 64.65 & & & 80.55 & 15.65 & & & & & & & 1.02 \\
\hline OS-80 & 1.85 & & 0.32 & & 1.23 & 5.24 & 71.53 & 13.08 & 1.25 & 2.37 & & & & 0.29 & 0.02 \\
\hline Mean & $\begin{array}{c}3.81 \pm \\
1.00\end{array}$ & $\begin{array}{c}0.36 \pm \\
0.07\end{array}$ & $\begin{array}{c}1.08 \pm \\
0.18\end{array}$ & $\begin{array}{c}30.37 \pm \\
5.04\end{array}$ & $\begin{array}{c}1.92 \pm \\
0.30\end{array}$ & $\begin{array}{c}4.80 \pm \\
1.41\end{array}$ & $\begin{array}{c}73.89 \pm \\
4.63\end{array}$ & $\begin{array}{c}14.61 \pm \\
1.60\end{array}$ & $\begin{array}{c}1.91 \pm \\
0.65\end{array}$ & $\begin{array}{c}3.98 \pm \\
0.84\end{array}$ & $\begin{array}{c}1.90 \pm \\
0.57\end{array}$ & $\begin{array}{c}0.34 \pm \\
0.02\end{array}$ & $\begin{array}{c}0.45 \pm \\
0.08\end{array}$ & $\begin{array}{c}0.14 \pm \\
0.01\end{array}$ & $\begin{array}{c}3.41 \pm \\
2.29\end{array}$ \\
\hline
\end{tabular}

mene $(32.81 \%), \beta$-Caryophyllene $(16.37 \%)$,Germacrene$\mathrm{D}(18.05 \%), \beta$-Ocimene $(17.69 \%)$ and Copane $(5.738 \%)$, as major constituents. The details of the oil profiling showing composition of three distinct core collections OS-50, OS-59, OS-70 are illustrated in Figure 1. The present results showed significant variability in the oil composition among thirty one core collections. Earlier report support the present observations [31]. A significant variation in chemical composition of the oil among the 270 accessions was recorded. Major constituents reported are eucalyptol, eugenol, and methyl chavicol. Composition of volatile oil of hybrids of Ocimum species for the purpose of studying the genetics of the chemical constituents showed that changes result in the new possible chemical formations through remote hybridization of various types [32].

The present data clearly indicates divergence with respect to essential oil composition in holy basil collected 

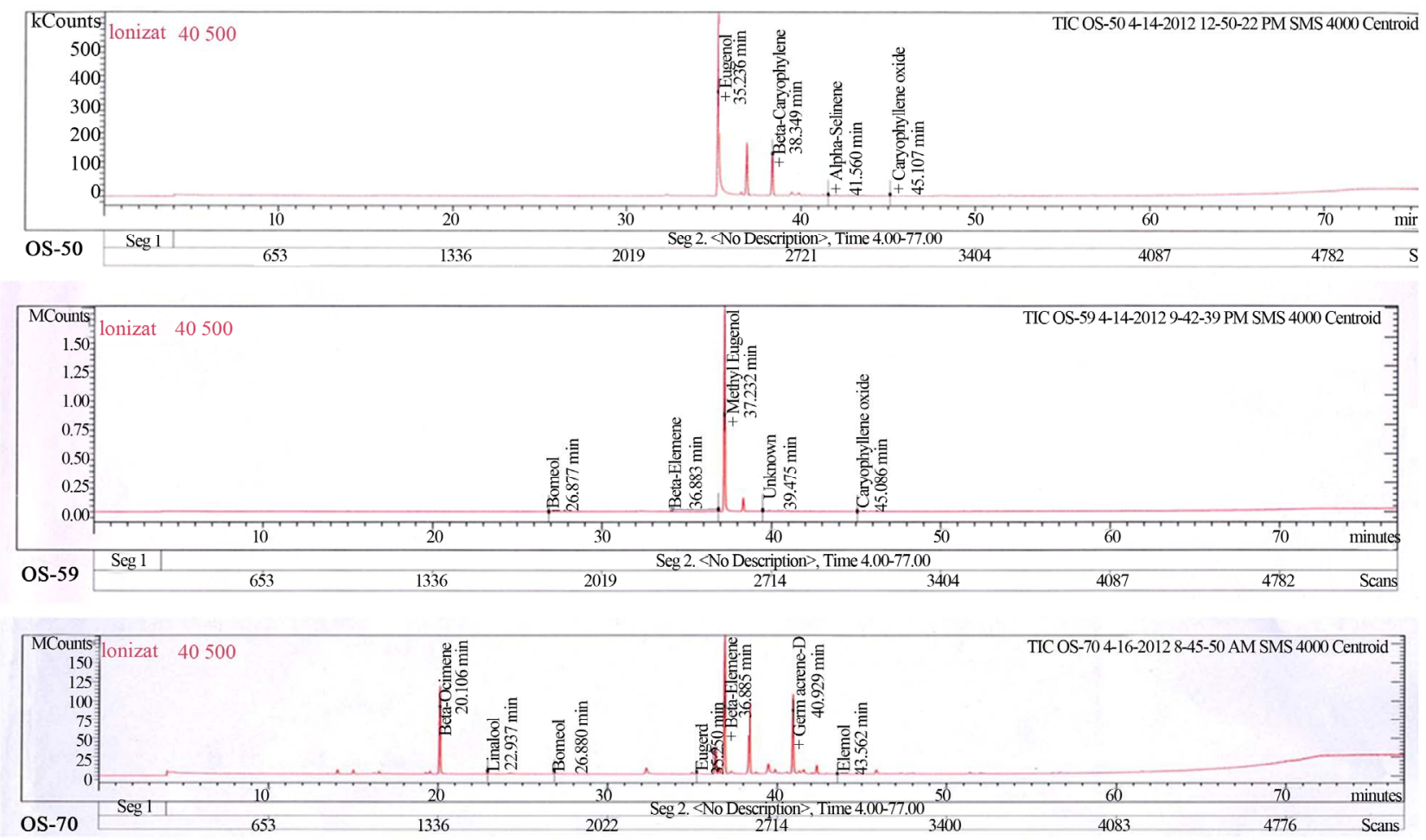

Figure 1. Legend GC/MS Chromatogram of selected core collections (a)-OS-50 Euqenol RT-35.236 min, $\beta$-Caryo-phyllene RT-38.349 min., $\alpha$ Selinene RT-41.560 min and Caryo-phyllene oxide RT-45.160, (b)-OS-59 Borneol RT-26.877min. Methyl Eugenol RT-37.232 min. Caryo-phyllene oxide RT-45.086) and (c)-OS-70 $\beta$ - Ocimene RT-20.106min. B-Elemene RT-36.885 min. Germa crene-D RT-40.929 $\beta$-Caryo-phyllene RT- 38.358 min. using analytical conditions as detailed in Materials and Methods.

from different eco-zones representing quite contrasting environments. Diversity among collected accessions which depicts divergence in chemical spectrum of essential oil could possibly be attributed due to soil type, $\mathrm{pH}$, extractable nutrients, temperature in various ecozones located in different parts of India. Secondly, relatively less conservative nature of the synthesis or accumulation of these constituents at harvest could possibly be another reason for variation in composition of oil. The collected data further validate and supports the earlier findings where the role of environmental conditions on basil productivity, oil content, and composition [16,33] have been documented. The present study and the earlier reports clearly point towards importance of germplasm evaluation in Ocimum sanctum, which needs to be carried out to identify high yielding chemotype rich in molecules of therapeutic importance. This will further help to exploit particular genotype for commercial purpose. The study lead to identify OS-50 and OS-59 collected from Gwalior from central India and Rajkot from western India, respectively as methyl eugenol (93.16\%) and eugenol (70.41\% ) rich cultivars. On the basis of data OS-70 collected from Patna (Bihar) was quite distinct which suggest that this collection could be characterized as distinct chemotype having $\beta$-Elemene (32.81\%), $\beta$-Caryophyllene $(16.37 \%)$, Germacrene-D (18.05\%) and $\beta$-Ocimene $(17.69 \%)$ as major constituents among the thirty one evaluated core collections.

\section{Conclusion}

The present investigation has broaden knowledge base with respect to existing diversity with respect to essential oil array in thirty one core collections of Ocimum sanctum from different eco-geographical conditions having contrasting environment. This has helped to identify elite clone rich in particular components which could be exploited further for bioprospection of biomolecules.

\section{Acknowledgements}

Authors are thankful to the Director CSIR-Indian Institute of Integrative Medicine, Jammu for providing the necessary facilities.

\section{REFERENCES}

[1] S. S. Balyan and P. Pushpangadan, "A Study on the Taxonomic Status and Geographic Distribution of the 
Genus, Ocimum," PAFAI, Vol. 10, No. 2, 1988, pp. 1319.

[2] S. Dutt, "Essential Oil of Ocimum sanctum L.," Proceedings of Indian Academy of Sciences, Section A, Vol. 9, No. 1, 1939, pp. 72-77.

[3] V. Singh, S. Amdekar and O. Verma, "Ocimum sanctum (tulsi): Bio-Pharmacological Activities," Webmed Central Pharmacology, Vol. 1, No. 10, 2010, pp. 1-7.

[4] R. N.Chopra, D. N. Roy, S. M. Ghosh and J. Malaria, "The Insecticidal and Larvicidal Action of the Essential Oils of Ocimum basilicum [L.] and Ocimum sanctum [L.]," Inxt. India, Vol. 4, 1941, pp. 109-112.

[5] R. Dupcar, "Gonopoti Chemical Composition of Ocimum sanctum," Congreso Luso-Espanol Farm, Vol. 3, 1952, pp. 187-191.

[6] J. E. Simon and D. R. Bubenheim, "Field Performance of American Basil Varieties," Journal of Herb, Spice and Medicinal Plant, Vol. 6, No. 1, 1987, pp. 1-4.

[7] J. E. Simon, J. Quinn and R. G. Murray, "Basil: A Source of Essential Oils," Advances in New Crops, Timber Press, Portland, 1990, pp. 484-489.

[8] S. Laskar, S. Majumdar, S. Ghosh, S. Laskar, S. Majumdar and S. Ghosh, "Variation of Major Constituents of Essential Oil of the Leaves of Ocimum sanctum L.," Journal of the Indian Chemical Society, Vol. 65, No. 4, 1988, pp. 301-302.

[9] M. L. Maheshwari, B. M. Singh and R. Gupta, "Essential Oil of Sacred Basil (Ocimum sanctum)," Indian Perfumer, Vol. 31, No. 2, 1987, pp. 137-145.

[10] H. Skaltsa-Diamantidis, O. Tzakou, A. Loukis and N. Argyriadou, "Analysis of the Essential Oil of Ocimum sanctum L.," Plantes Medicinales et Phytotherapie, Vol. 24, No. 2, 1990, pp. 79-81.

[11] R. F. Vieira, R. J. Grayer, A. Paton and J. E. Simon, "Genetic Diversity of Ocimum gratissimum L. Based on Volatile Oil Constituents, Flavonoids and RAPD Markers," Biochemical Systematics and Ecology, Vol. 29, No. 3, 2001, pp. 287-304. doi:10.1016/S0305-1978(00)00062-4

[12] S. D. Ahmad and I. Khaliq, "Top of Form Morpho-Molecular Variability and Heritability in Ocimum sanctum Genotypes from Northern Himalayan Region of Pakistan," Pakistan Journal of Biological Sciences, Vol. 5, No. 10, 2002, pp. 1084-1087. doi:10.3923/pjbs.2002.1084.1087

[13] R. P. Adams, "Identification of Essential Oil Components by Gas Chromatography/Mass Spectroscopy," Allured Publishing Corporation, Carol Stream, 2006.

[14] M. Anwar, D. D. Patra, S. Hand, A. Kumar, A. A. Naqvi and S. P. S. Khanuja, "Effect of Organic Manures and Inorganic Fertilizer on Growth, Herb and Oil Yield, Nutrient Accumulation, and Oil Quality of French Basil," Soil Science and Plant Analysis, Vol. 36, No. 13-14, 2005, pp. 1737-1746. doi:10.1081/CSS-200062434

[15] K. Bowes and V. D. Zheljazkov, "Ocimum sanctum L. and Ocimum basilicum L. Grown in Nova Scotia, Canada Show Potential as Essential Oil Crops," Journal of the American Society for Horticultural Science, Vol. 129, 2004, pp. 789-794.
[16] M. Marotti and R. Piccaglia and E. Giovanelli, "Differences in Essential Oil Composition of Basil (Ocimum basilicum L.) Italian Cultivars Related to Morphological Characteristics," Journal of Agricultural and Food Chemistry, Vol. 44, No. 12, 1996, pp. 3926-3929. doi:10.1021/jf9601067

[17] V. D. Topalov, "Essential Oil and Medicinal Plants," Hr. G. Danov Press, Plovdiv, 1962, pp. 106-153.

[18] J. A. Pino, E. Roncal, A. Rosado and I. Goire, "The Essential Oil of Ocimum basilicum L. from Cuba," Journal of Essential Oil Research, Vol. 6, No. 1, 1994, pp. 89-90. doi:10.1080/10412905.1994.9698333

[19] S. B. Wetzeil, H. Kruger, K. Hammer and K. Bachmann, "Investigations on Morphological and Molecular Variability of Ocimum L. Species," Journal of Herb, Spice and Medicinal Plant, Vol. 9, 2002, pp. 8183-8188.

[20] J. E. Simon, M. R. Morales, W. B. Phippen, R. F. Vieira and Z. Hao, In: J. Janick and J. E. Simon, Eds., Perspectives on New Crops and New Uses, Basil: A Source of Aroma Compounds and Popular Culinary and Ornamental Herb, 1999, pp. 499-505.

[21] R. D. Gang, N. L. C. Zubieta, F. Chen, T. Beuerle, E. Lewinsohn, P. J. Noel and E. Pichersky, "Characterization of Phenylpropene $O$-Methyltransferases from Sweet Basil. Facile Change of Substrate Specificity and Convergent Evolution within a Plant $O$-Methyltransferase Family," The Plant Cell, Vol. 14. No. 2, 2002, pp. 505-519. doi: $10.1105 / \mathrm{tpc} .010327$

[22] J. Grossman, "Botanical pesticides in Africa," Integrated Pest Management Programme Practice, Vol. 15, 1993, pp. 1-9.

[23] C. Sisk, H. Shorey, R. Gerber and L. Gaston, "Semiochemicals That Disrupt Foraging by the Argentine Ant (Hymenoptera: Formicidae): Laboratory Bioassays," Journal of Economic Entomology, Vol. 89, 1985, pp. 381-385.

[24] D. Obeng-Ofori and C. Reichmuth, "Bioactivity of Eugenol, a Major Component of Essential Oil of Ocimum suave (Wild.) against Four Species of Stored-Product Coleoptera," Integrated Pest Management Programme Practice, Vol. 43, 1997, pp. 89-94.

[25] N. Chatterjee, Sukul, S. Laskar and S. Ghoshmajumdar, "Nematicidal Principles from Two Species of Lamiaceae, Ocimum sanctum and Ocimum basilicum," The Journal of Nematology, Vol. 14, 1982, pp. 118-122.

[26] N. Sangwan, B. Verman, K. Verma and K. Dhindsa, "Nematicidal Activity of Some Essential Plant Oils," Pesticide Science, Vol. 28, No. 3, 1990, pp. 331-335. doi:10.1002/ps.2780280311

[27] M. Karapinar and S. Aktug, "Inhibition of Foodborne Pathogens by Thymol, Eugenol, Menthol and Anethole," International Journal of Food Microbiology, Vol. 4, 1987, pp. 161-166.

[28] S. Adams and M. Weidenborner, "Mycelial Deformations of Cladosporium herbarum Due to the Application of Eugenol or Carvacrol," Journal of Essential Oil Re- search, Vol. 8, No. 5, 1996, pp. 535-540. doi:10.1080/10412905.1996.9700682 
[29] S. Miyao, "Inhibitory Effects of Ethanol Extract of Mace and Eugenol on the Growth of Microorganisms Isolated from Vienna Sausages," Nihon Shokuhin Eisei Gakkai, Vol. 16, No. 6, 1975, pp. 412-416. doi:10.3358/shokueishi.16.412

[30] R. Shukla and V. Prasad, "Population Fluctuations of the Oriental Fruit Fly, Dacus Dorsalis Hendel, in Relation to Hosts and Abiotic Factors," Tropical Pest Management, Vol. 31, No. 4, 1985, pp. 273-275. doi:10.1080/09670878509370999

[31] H. Kruger, S.B. Wetzel and B. Zeiger, "The Chemical Variability of Ocimum Species," Journal of Herb, Spice and Medicinal Plant, Vol. 9, No. 4, 2002, pp. 335-344. doi:10.1300/J044v09n04 11

[32] T. I. Knishevetskaya, "Composition of Essential Oil of Hybrid Basil," Trudy Gonsudarrst, Nikitakoyo Botan, Soda, Vol. 27, 1939, pp. 29-36.

[33] J. A. Javanmardi, A. Khalighi, H. P. Kashi, Bais and J.M. Vivanco, "Chemical Characterization of Basil (Ocimum basilicum L.) Found in 'Local' Accessions and Used in Traditional Medicines in Iran," Journal of Agricultural and Food Chemistry, Vol. 50, 2002, pp. 5878-5883. doi:10.1021/jf020487q 